\title{
Author Correction: Spatial fidelity of workers predicts collective response to disturbance in a social insect
}

\author{
James D. Crall (10 1, Nick Gravish², Andrew M. Mountcastle ${ }^{3}$, Sarah D. Kocher ${ }^{4}$, Robert L. Oppenheimer ${ }^{5}$, \\ Naomi E. Pierce (iD ${ }^{1} \&$ Stacey A. Combes ${ }^{6}$
}

Correction to: Nature Communications https://doi.org/10.1038/s41467-018-03561-w, published online 03 April 2018

The original version of the Article contained incorrect citation information in reference 67. The reference should read "Russell, A. L., Morrison, S. J., Moschonas, E. H. \& Papaj, D. R. Patterns of pollen and nectar foraging specialization by bumblebees over multiple timescales using RFID. Sci. Rep. 7, 1-13 (2017)." This error has now been corrected in the PDF and HTML versions of the Article.

Published online: 31 May 2018

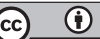

Open Access This article is licensed under a Creative Commons Attribution 4.0 International License, which permits use, sharing, adaptation, distribution and reproduction in any medium or format, as long as you give appropriate credit to the original author(s) and the source, provide a link to the Creative Commons license, and indicate if changes were made. The images or other third party material in this article are included in the article's Creative Commons license, unless indicated otherwise in a credit line to the material. If material is not included in the article's Creative Commons license and your intended use is not permitted by statutory regulation or exceeds the permitted use, you will need to obtain permission directly from the copyright holder. To view a copy of this license, visit http://creativecommons.org/licenses/by/4.0/.

(c) The Author(s) 2018

\footnotetext{
${ }^{1}$ Department of Organismic and Evolutionary Biology, Harvard University, 26 Oxford St., Cambridge, MA 02143, USA. ${ }^{2}$ Mechanical and Aerospace Engineering, University of California San Diego, Engineer Ln, San Diego, CA 92161, USA. ${ }^{3}$ Department of Biology, Bates College, 2 Andrews Road, Lewiston, ME 04240, USA. ${ }^{4}$ Lewis-Sigler Institute for Integrative Genomics, Princeton University, Princeton, NJ 08540, USA. ${ }^{5}$ Department of Biological Sciences, University of New Hampshire, 105 Main St., Durham, NH 03824, USA. ${ }^{6}$ Department of Neurobiology, Physiology, and Behavior, University of California Davis, Davis, CA 95616, USA. Correspondence and requests for materials should be addressed to J.D.C. (email: jcrall@oeb.harvard.edu)
} 